\title{
Convergence On A Global Accounting Standard For Leases - Impacts Of The FASB/IASB Project On Lessee Financial Statements
}

Bob G. Kilpatrick, Northern Arizona University, USA

Nancy L. Wilburn, Northern Arizona University, USA

\begin{abstract}
In this paper, we compare the current U.S. GAAP and IFRS lease accounting rules with the proposed rules under the joint FASB/IASB project's exposure draft as modified by their redeliberation decisions. Additionally, we discuss the potential financial statement impacts of the proposed changes and provide examples of the effects of constructive capitalization of operating leases on the financial statements and resulting ratios for matched pairs of Global Fortune 500 companies in industries, with each pair consisting of a company that follows U.S. GAAP versus one that follows IFRS.
\end{abstract}

Keywords: Lease Accounting; Financial Statement Impacts

\section{INTRODUCTION}

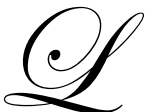

ease obligations are widely considered a significant source of off-balance sheet financing. Indeed, a Securities and Exchange Commission (SEC) report estimates the total off-balance sheet liability for U.S. financial statement issuers at over $\$ 1.25$ trillion (SEC, 2005). Due to the significance of this offbalance sheet liability, the SEC recommended that the Financial Accounting Standards Board (FASB) reconsider current U.S. GAAP "rules-based" lease accounting standards and guidance. Indeed, the so-called "bright-line" tests for classification as a capital lease under U.S. GAAP are often cited as a major criticism, allowing companies to intentionally structure lease arrangements to avoid balance sheet inclusion which does not provide a faithful representation of leasing transactions. However, even under the "principles-based" guidance provided in International Financial Reporting Standards (IFRS), capital lease indicators are interpreted similarly to the brightline tests and, as a result, lease classification is often the same as under U.S. GAAP and therefore excluded from the statement of financial position (Ernst \& Young, March 2010).

As one of their priority convergence projects, the FASB and International Accounting Standards Board (IASB) are working jointly to comprehensively reconsider the existing accounting rules for leases, and have issued an exposure draft (ED) with their proposals (FASB, August 2010). The ED reflects the Boards' mutual goal to develop a model to improve financial reporting by increasing comparability and transparency in lease accounting by ensuring that all assets and liabilities arising from lease contracts are recognized in the statement of financial position. The Boards are redeliberating their proposals to consider feedback from constituents and have already made tentative decisions that will reflect changes from the ED, and have revised their target date for publishing a final standard to the second half of 2011 (FASB, April 2011).

\section{ACCOUNTING FOR LEASES - BASIC TREATMENT UNDER CURRENT AND PROPOSED RULES}

The primary sources for current lease accounting rules under U.S. GAAP and IFRS are FASB ASC 840 and IAS 17, respectively. In general terms, both standards require lessees to classify leasing transactions as either a 
capital lease (IFRS uses the term finance lease) or an operating lease. Capital/finance leases are accounted for similar to a purchase of the underlying asset with recognition of the leased asset and obligation on the balance sheet. The lessee depreciates the leased asset and apportions lease payment between a finance charge and a reduction of the outstanding obligation. If classified as an operating lease, the lessee accounts for the lease as a rental, i.e., recognizes lease payments as rental expense, usually on a straight-line basis, with no balance sheet recognition of the leased asset or obligation.

Current criteria, summarized in Table 1, for lessee treatment as a capital/finance lease under U.S. GAAP and IFRS are somewhat similar and intend to evaluate whether the lease transfers to the lessee substantially all the risks and rewards incidental to ownership of the leased asset. Both standards have identical criteria concerning ownership transfer and bargain purchase option at the conclusion of the lease term. However, U.S. GAAP creates two all-or-nothing "bright-line" tests (criteria \#3 and \#4 in Table 1) - a lease term of $75 \%$ or more of the asset's remaining economic life, and a present value of minimum lease payments of $90 \%$ or more of the asset's fair value. IFRS avoids these bright-line tests by employing more judgmental tests, using the terms "major part" and "substantially all" in place of the $75 \%$ and $90 \%$ tests, respectively. IFRS contains four additional indicators that suggest whether a lease might be considered a finance lease.

Table 1

Current Criteria for Lessee Classification as Capital/Finance Lease

\begin{tabular}{l} 
U.S. GAAP \\
\hline 1. The lease transfers ownership to the lessee at the end of the \\
lease term; or
\end{tabular}

3. The term of the lease (plus any bargain renewal option) is equal to or greater than $75 \%$ of the estimated economic life of the leased property; or

4. The present value of the minimum lease payments is equal to or greater than $90 \%$ of the fair value of the leased property.
1. The lease transfers ownership to the lessee at the end of the lease term; or

2. The lease contains a bargain purchase option, under which the lessee can purchase the leased property at a price significantly below the expected fair value of the leased property at the end of the lease term and that the option's exercise is reasonably certain; or

3. The term of the lease (plus any bargain renewal option) is for a major part of the estimated economic life of the leased property if title is not transferred; or

4. The present value of the minimum lease payments amounts to at least substantially all of the fair value of the leased property; or

5. The leased asset is of such specialized nature that only the lessee can use the asset without major modifications; or

6. The leased asset is of such specialized nature that only the lessee can use the asset without major modifications; or

7. The lessee bears any lessor losses associated with lease cancellation; or

8. All gains or losses from fluctuations in the residual fair value accrue to the lessee.

The fundamental change proposed under the joint project's ED is utilization of a single "right-of-use" lease accounting model that would require capitalization of all leases in the lessee's statement of financial position. This approach requires a lessee to recognize an asset representing the lessee's right-to- use the leased item for the lease term and a liability for its obligation to pay rentals. However, the Boards have subsequently decided to allow an exception for short-term leases with a maximum possible term of 12 months or less that would allow lessees to account for these leases similar to current operating leases rather than under the right-of-use model (FASB, March $31,2011)$. 
For timing of expense recognition for capitalized leases, the Boards have tentatively decided in their redeliberations that leases should be classified as either finance leases or other-than-finance leases. The expense recognition pattern for finance and other-than-finance leases would be essentially the same as capital and operating leases, respectively, under current U.S. GAAP. Determination of whether a lease is a finance lease would be made using the classification principles under current IFRS (FASB, March 31, 2011).

\section{IMPACT OF PROPOSED RULES ON LESSEE FINANCIAL STATEMENTS}

The requirement for capitalization of all leases will have a significant impact on the statement of financial position of any company that utilizes operating leases to provide a substantial amount of its property, plant, and equipment. The major impacts on the balance sheet will be to increase assets and liabilities (both current and longterm) for amounts previously excluded under operating leases. For leases classified as finance leases, the impact on the income statement will result primarily from the acceleration of expense recognition due to interest element in the new liability versus straight-line expense recognition of rentals associated with operating leases; however, for leases classified as other-than-finance leases, the pattern of expense recognition would be consistent with the current pattern for operating leases. On the statement of cash flows, the most significant impact will result for finance leases from the change in classification of the cash outflows from operating activities (as rental expense under operating leases) to financing activities.

\section{CONSTRUCTIVE CAPITALIZATION OF OPERATING LEASES}

The FASB notes that many users of financial statements adjust the amounts presented in the statement of financial position to reflect the assets and liabilities arising from operating leases (FASB, 2011). Therefore, we perform constructive capitalization of operating leases for six Fortune Global 500 companies to compare the primary impacts of the lease accounting proposals on U.S. GAAP followers and IFRS followers. This process involves using the operating lease disclosures to estimate the amount of liabilities and assets that would have been reported on the balance sheet if the operating lease had been treated as a capital lease from its inception.

For this analysis, we chose companies from the airline, retail food and drug, and general merchandisers industries, which are among the industries predicted to be most affected by the lease accounting changes (Johnson, 2009). We matched these firms based on industry and size using Fortune Global 500 rankings, with each pair consisting of a U.S. company that uses U.S. GAAP and a U.K. company that uses IFRS. The resulting U.S. and U.K. firms in each industry are, respectively: airlines - United Airlines and British Airways; retail food and drug Kroger and Tesco; and general merchandisers - Kohl's Corporation, and Marks and Spencer. Our constructive capitalization computations are based on a similar process developed by Imhoff, et al. (1991), using the following uniform assumptions: (a) 9\% discount rate for the future minimum rentals, based on average estimated rates from capital lease disclosures; (b) average remaining life of 15 years for operating leases; (c) end-of-year cash flows; (d) net effect on the current period's net income of zero; (e) unrecorded asset equals $70 \%$ of the unrecorded obligation; and (f) effective tax rates of $40 \%$ (U.S.) and $30 \%$ (U.K.).

Table 2 presents selected lease information originally reported by companies and the results of the estimated amounts resulting from the operating lease capitalization procedures. With respect to current classification of operating leases versus capital leases, comparisons of companies within specific industries show very different results. For airlines, the ratio of operating to capital leases for the U.S. company is 4.4 times, whereas the U.K. company is only 1.3 times. However, the retail food and drug companies exhibit the opposite pattern, with the U.K company's ratio of 45.0 times substantially larger than the U.S. company of 14.7 times. Both the U.S. and U.K. general merchandiser companies utilize significantly high ratios of operating leases as compared to capital/finance, at 39.8 times and 45.0 times, respectively.

As expected, capitalization of operating leases would result in negative impacts for all companies on two key ratios, with increases in the debt/asset ratio and decreases in return on assets (ROA). The extent of the impacts, however, is quite variable both among and within industries. Because the general merchandisers employ operating leases to a greater extent than the other industries, capitalization of these leases would have a greater impact on lease assets as a percentage of total assets and lease obligations as a percentage of total liabilities, which results in 
predictably larger impacts on their debt/asset ratios and ROAs. However, comparing the U.S. companies with their U.K. counterparts within industries, no clear pattern emerges. Intuitively, one would predict that a company with a higher extent of leases currently classified as operating would have more significant impacts on its debt/asset ratio and ROA from capitalizing its leases. However, the U.S. airline company utilizing proportionately more operating leases than the U.K. company has a smaller impact on its debt/asset ratio although has a higher impact on ROA. For retail food and drug, the U.K. company with proportionately more operating leases than the U.S. company does have a higher impact on its debt/asset ratio but a slightly smaller impact on ROA. Finally, for the general merchandiser companies, although both the U.S. and U.K. companies utilize similar proportions of operating leases, the U.S. company had larger impacts on both its debt/asset ratio and ROA.

Table 2

Summary Results - Impact of Operating Lease Capitalization

\begin{tabular}{|c|c|c|c|c|c|c|}
\hline \multirow{4}{*}{$\begin{array}{l}\text { Ratio of operating to capital leases: } \\
\text { (undiscounted minimum payments) }\end{array}$} & \multicolumn{6}{|c|}{ Industry } \\
\hline & \multicolumn{2}{|c|}{$\underline{\text { Airlines }}$} & \multicolumn{2}{|c|}{$\underline{\text { Retail Food \& Drug }}$} & \multicolumn{2}{|c|}{$\begin{array}{c}\text { General } \\
\text { Merchandisers }\end{array}$} \\
\hline & $\underline{U S C O}$ & $\underline{U}$ U Co. & USCo. & $\underline{U K C o}$. & USCo. & $\underline{U K}$ Co. \\
\hline & 4.4 & 1.3 & 14.7 & 45.0 & 39.8 & 45.0 \\
\hline \multicolumn{7}{|l|}{ Impacts from operating lease capitalization: } \\
\hline \multicolumn{7}{|l|}{ Overall Balance Sheet Amounts: } \\
\hline$\%$ Increase in Total Assets & $24.2 \%$ & $9.8 \%$ & $12.5 \%$ & $12.0 \%$ & $29.0 \%$ & $20.2 \%$ \\
\hline$\%$ Increase in Total Liabilities & $26.4 \%$ & $15.9 \%$ & $19.9 \%$ & $22.9 \%$ & $90.3 \%$ & $37.9 \%$ \\
\hline$\%$ Decrease in Equity & $-41.3 \%$ & $-14.9 \%$ & $-15.1 \%$ & $-11.3 \%$ & $-12.5 \%$ & $-19.9 \%$ \\
\hline \multicolumn{7}{|l|}{ Total Debt / Total Assets Ratios: } \\
\hline Pre-capitalization & $115.0 \%$ & $80.2 \%$ & $78.8 \%$ & $68.1 \%$ & $40.3 \%$ & $69.4 \%$ \\
\hline Post-capitalization & $117.1 \%$ & $84.7 \%$ & $84.0 \%$ & $74.7 \%$ & $59.5 \%$ & $79.6 \%$ \\
\hline$\%$ Change in Debt/Asset Ratio & $1.8 \%$ & $5.5 \%$ & $6.6 \%$ & $9.7 \%$ & $47.6 \%$ & $14.7 \%$ \\
\hline \multicolumn{7}{|l|}{ Return on Assets: } \\
\hline Pre-capitalization & $-3.5 \%$ & $-4.0 \%$ & $5.1 \%$ & $5.1 \%$ & $7.5 \%$ & $7.3 \%$ \\
\hline Post-capitalization & $-2.8 \%$ & $-3.6 \%$ & $4.6 \%$ & $4.5 \%$ & $5.8 \%$ & $6.1 \%$ \\
\hline$\%$ Change in Return on Assets & $-19.5 \%$ & $-8.9 \%$ & $-11.1 \%$ & $-10.7 \%$ & $-22.5 \%$ & $-16.8 \%$ \\
\hline
\end{tabular}

\section{CONCLUSIONS AND LIMITATIONS}

A popular argument contends that the bright-line tests that exist under U.S. accounting rules encourages U.S. companies to intentionally structure lease arrangements as operating leases, thus excluding the obligations from their balance sheets - essentially a "form-over-substance" argument. However, the wide variation in the proportion of leases classified as operating or finance under the principles-based guidance by the IFRS companies relative to their U.S. counterparts included in this study do not support that assertion. Nevertheless, the proposal to include virtually all leases on the balance sheet can have significant impacts on financial statements and resulting ratios for both U.S. GAAP and IFRS followers. Two limitations of this study are important to note. One is that the impacts reported are company-specific. The other is that the ultimate impacts will be based on the final standards issued by the FASB and IASB.

\section{ACKNOWLEDGEMENTS}

We gratefully acknowledge the financial support for this research provided by Clifton Gunderson LLP. 


\section{AUTHOR INFORMATION}

Bob G. Kilpatrick is a Professor of Accounting at The W. A. Franke College of Business at Northern Arizona University. E-mail: bob.kilpatrick@nau.edu

Nancy L. Wilburn is a Professor of Accounting at The W. A. Franke College of Business at Northern Arizona

University. E-mail: nancy.wilburn@nau.edu

\section{REFERENCES}

1. $\quad$ Ernst \& Young LLP, US GAAP vs. IFRS -- The Basics (March 2010).

2. Financial Accounting Standards Board (FASB), FASB Accounting Standards Codification Topic 840, online, www.FASB.org.

3. Financial Accounting Standards Board (FASB), Financial Accounting Series, Exposure Draft, "Proposed Accounting Standards Update, Leases (Topic 840)," (Norwalk, CT: FASB, August 17, 2010).

4. Financial Accounting Standards Board (FASB), "Project Update, Leases-Joint Project of the FASB and IASB," Technical Plan last updated March 31, 2011, online, www.FASB.org.

5. Financial Accounting Standards Board (FASB), "Progress report on IASB-FASB convergence work," April 21, 2011, online, www.FASB.org.

6. Imhoff, E.A., R.C. Lipe, and D.W. Wright, "Operating Leases: Impact of Constructive Capitalization," Accounting Horizons, 5(1) (1991), pp. 51-63.

7. International Accounting Standards Board (IASB), International Accounting Standard (IAS) 17, "Leases," (London: IASB, 1997).

8. Johnson, Sarah, "When Is a Lease a Lease?" CFO.com, (11/2/09).

9. Securities and Exchange Commission Office of the Chief Accountant, Office of Economic Analysis, and Division of Corporation Finance, Report and Recommendations Pursuant to Section 401(c) of the Sarbanes-Oxley Act of 2002 on Arrangements with Off-Balance Sheet Implications, Special Purpose Entities, and Transparency of filings by Issuers, June 15, 2005. 


\section{NOTES}

